\title{
Measurement and modelling ozone fluxes over a cut and fertilized grassland
}

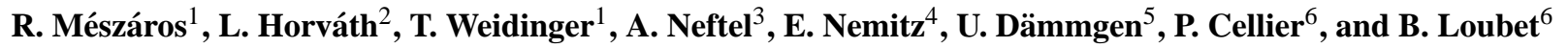 \\ ${ }^{1}$ Department of Meteorology, Eötvös Loránd University, Pázmány Péter sétány 1/A, P.O. Box 32, 1518 Budapest, Hungary \\ ${ }^{2}$ Hungarian Meteorological Service (HMS), Budapest, Hungary \\ ${ }^{3}$ Institute of Environmental Protection and Agriculture, Zürich, Switzerland \\ ${ }^{4}$ Centre for Ecology and Hydrology (CEH), Penicuik, Midlothian, UK \\ ${ }^{5}$ Institute for Agroecology, Federal Agricultural Research Centre, Braunschweig, Germany \\ ${ }^{6}$ National Institute for Agronomic Research (INRA), Thiverval-Grignon, France
}

Received: 22 October 2008 - Published in Biogeosciences Discuss.: 21 January 2009

Revised: 31 August 2009 - Accepted: 31 August 2009 - Published: 2 October 2009

\begin{abstract}
During the GRAMINAE Integrated Experiment between 20 May and 15 June 2000, the ozone flux was measured by the eddy covariance method above intensively managed grassland in Braunschweig, northern Germany. Three different phases of vegetation were covered during the measuring campaign: tall grass canopy before cut (29 May 2000 ), short grass after cut, and re-growing vegetation after fertilization (5 June 2000). Results show that beside weather conditions, the agricultural activities significantly influenced the $\mathrm{O}_{3}$ fluxes. After the cut the daytime average of the deposition velocity $\left(v_{d}\right)$ decreased from $0.44 \mathrm{~cm} \mathrm{~s}^{-1}$ to $0.26 \mathrm{~cm} \mathrm{~s}^{-1}$ and increased again to $0.32 \mathrm{~cm} \mathrm{~s}^{-1}$ during the third period. Detailed model calculations were carried out to estimate deposition velocity and ozone flux. The model captures the general diurnal patter of deposition, with $v_{d}$ daytime values of $0.52,0.24$, and $0.35 \mathrm{~cm} \mathrm{~s}^{-1}$ in the first, second and third period, respectively. Thus the model predicts a stronger response to the cut than the measurements, which is nevertheless smaller than expected on the basis of change in leaf area. The results show that both cut and fertilization have complex impacts on fluxes. Reduction of vegetation by cutting decreased the stomatal flux initially greatly, but the stomatal flux recovered to $80 \%$ of its original value within a week. At the same time, the non-stomatal flux appears to have increased directly after the cut, which the model partially explains by an increase in the deposition to the soil. A missing sink after the cut may be the chemical interaction with biogenic volatile organic compounds released after the cut and exposed senescent plant parts, or the increase in soil NO emissions after fertilization. Increased canopy tempera-
\end{abstract}

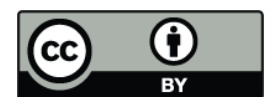

Correspondence to: R. Mészáros (mrobi@nimbus.elte.hu) tures may also have promoted ozone destruction on leaf surfaces. These results demonstrate the importance of canopy structure and non-stomatal pathways on $\mathrm{O}_{3}$ fluxes.

\section{Introduction}

Tropospheric ozone $\left(\mathrm{O}_{3}\right)$ has important effects on human health (Weschler, 2006) and plant functioning (Emberson, 2003). The background $\mathrm{O}_{3}$ concentration has increased by a factor of two in the last century and will continue to rise according to model predictions (Vingarzan, 2004). Although significant progress has been made in the last decades in understanding the cycling of $\mathrm{O}_{3}$ in the troposphere (Crutzen et al., 1999), there are still gaps in our understanding of the deposition processes (Ashmore et al., 2007). This particularly applies to the quantification of dry deposition, and in particular the fraction of the $\mathrm{O}_{3}$ that is absorbed through the stomata (and can therefore cause plant damage) and the controls of the non-stomatal deposition. Within canopies, ozone can undergo chemical interactions with NO (Duyzer et al., 1997), biogenic volatile organic compounds (VOCs) and hydroxyl and nitrate radicals (Fuentes et al., 2007), and it can be destroyed on leaf surfaces and soils. While gas-phase chemistry has been suggested to dominate the non-stomatal in canopies emitting large amounts of VOCs (e.g. Blodgett Forest, CA; Kurpius and Goldstein, 2003), most studies have explained non-stomatal fluxes with surface processes, which is consistent with studies that show $\mathrm{O}_{3}$ to be destroyed at non-biological surfaces (e.g. Cape et al., 2009). Even where canopy chemical reactions only account for a small fraction of the $\mathrm{O}_{3}$ flux they can substantially modify the NO and VOCs fluxes.

Published by Copernicus Publications on behalf of the European Geosciences Union. 
Ozone deposition has been measured above a number of ecosystems, including grasslands (e.g. Padro et al., 1998). Within-canopy gradients of ozone show a strong depletion of ozone concentrations immediately above the surface of grasslands, especially at low friction velocities (Jäggi et al., 2006). The division of the $\mathrm{O}_{3}$ flux into its stomatal and non-stomatal component is complex for grassland due to the range of species present and their location within the canopy (Bassin et al., 2007). Hence, it is important to measure $\mathrm{O}_{3}$ fluxes above grasslands to help characterise the impacts of $\mathrm{O}_{3}$ on plant communities and to improve our understanding of the non-stomatal $\mathrm{O}_{3}$ fluxes (Zhang et al., 2006).

In the framework of the Braunschweig Integrated Experiment of the GRAMINAE (GRassland AMmonia INteractions Across Europe) EU project (Sutton et al., 2009a), dry deposition of $\mathrm{O}_{3}$ was measured by the eddy-covariance method. Here results are presented, together with the application of a deposition model, to provide an evaluation of the ratio of stomatal and non-stomatal fluxes. The campaign was designed so as to allow investigation of effect of agricultural activities on the respective fluxes, including the effects of cutting and fertilization on the measuring site. Thus, three different periods were covered in the campaign, namely: 1) pre cutting (20 May 2000-29 May 2000); 2) post cutting, pre fertilizing (29 May 2000-5 June 2000) and 3) regrowth, post fertilizing (5 June 2000-15 June 2000). At the beginning of period 3, on 5 June 2000, calcium ammonium nitrate fertilizer $\left(108 \mathrm{~kg} \mathrm{Nha}^{-1}\right)$ was applied.

Because the number of stomata is strongly reduced as a consequence of the cut, the comparison of $\mathrm{O}_{3}$ fluxes and deposition velocities between pre and post cut periods gives a good tool to study the effect of the decrease of the active vegetation surface on the dry deposition processes. Similarly, the fertilization of the grass can cause some alteration of the physiological state of plant, and this also affects the aperture of stomata and the fluxes.

The main aims of this study were the following: analysis of the effects of agricultural activities (cutting and fertilization) on ozone fluxes, parameterisation and estimation of the deposition velocity and flux of ozone using a detailed deposition model, and evaluation of the ratio and controls of stomatal to non-stomatal ozone fluxes to the grass canopy during the different growth phases.

\section{Field site and measurements}

\subsection{Site description}

Ozone fluxes were measured during the Braunschweig GRAMINAE campaign from 21 May to 15 June 2000 over intensively managed grassland at the experimental fields of the Federal Agricultural Research Centre (Bundesforschungsanstalt für Landwirtschaft - FAL, Braunschweig Germany). The measuring site is located at latitude $52^{\circ} 18^{\prime} \mathrm{N}$ and longitude $10^{\circ} 26^{\prime} \mathrm{E}$ at $79 \mathrm{~m}$ above mean sea level surrounded by 12 ha arable and other managed grassland fields dominated by Lolium perenne, and has sandy soil. The available fetch was approximately $300 \mathrm{~m}$ to the west and east, $200 \mathrm{~m}$ to the south and 50 to $100 \mathrm{~m}$ to the north. The grass was cut at 06:00-10:00 UTC on 29 May, and was then lifted on 31 May. One week after cutting the field was fertilized at 06:00-07:00 on 5 June 2000. At the time of cutting, the grass was $0.75 \mathrm{~m}$ tall, with a single sided LAI of 3.06. Cutting reduced the vegetation to a height of $0.07 \mathrm{~m}$ with an LAI of 0.14 . At the end of the measurements, the canopy height was $0.34 \mathrm{~m}$ with an LAI of 1.5 . For details of the overall experimental setup, soil and vegetation see Sutton et al. (2009a).

\subsection{Measurements}

At the field site, in the frame of the integrated experiment, detailed micrometeorological measurements were made with eddy flux towers and gradient systems. Intercomparison and assessment of the micrometeorological measurements and turbulence exchange parameters, as well as a description of consensus micrometeorological dataset can be found in $\mathrm{Ne}-$ mitz et al. (2009a). In this study, these consensus data were used. Additionally, other measurement records were used for the model calculations. The soil water content was sampled using TDR (Time Domain Reflectometry) at different soil depth (for details see Sutton et al., 2009a). Dry and wet canopy was distinguished based on leaf surface wetness measurements (Burkhardt et al., 2009). Single sided Leaf Area Index (LAI) was periodically measured by LAI meter, and for the whole measuring period a simple function was fitted to the measured values before and after cut based on vegetation height, which was continuously measured with a canopy height meter.

\subsection{Ozone flux measurements}

Ozone fluxes were measured using the eddy-covariance method by means of a Solent $1012 \mathrm{R}$ research ultrasonic anemometer (Gill Instruments) and a NOAA fast response ozone sensor (NOAA, 1996), positioned at $2 \mathrm{~m}$ above ground. This sensor is based on the dry chemi-luminescent reaction of a silica gel chromatography disk impregnated with coumarin (Speuser et al., 1989). One drawback of this analyser is that the reactivity of the fluorescent dye is gradually exhausted, requiring periodic replacement and continuous recalibration to evaluate the ozone flux $\left(F_{\mathrm{O}_{3}}\right)$. The plates were hence changed every five to six days, and the sensor output $(U$ in $\mathrm{mV}$ ) was "calibrated" by linear regression over 3 to $48 \mathrm{~h}$ periods against a reference ozone monitor. The reference ozone concentration was measured at the Broitzem urban background measuring site, $5 \mathrm{~km} \mathrm{~S}$ from the flux site, providing $30 \mathrm{~min}$ averaged concentrations $\left(\chi_{\mathrm{O}_{3}}\right.$ in $\mathrm{ppb}$ ), from which a linear calibration was obtained for each disk:

$\chi_{\mathrm{O}_{3}}=a U+b \quad[\mathrm{ppb}]$, 
where the unit of $a$ is $\mathrm{ppb} / \mathrm{mV}$. This calibration was used to turn the analyser voltages into $\mathrm{O}_{3}$ concentration prior to flux calculation.

Based on Diem (2003) the ozone concentration measurements should be representative up to $10 \mathrm{~km}$, therefore we have assumed that in this flat, suburban region there are no significant differences between ozone concentrations in the background station and the flux site. However, it is obvious that local effects could cause some spatial differences in ozone concentration. Therefore, any periods when the correlation coefficient between reference ozone concentration and fast response ozone measurements was lower than 0.8 were excluded from the analysis. It should be noted that the ozone flux is mainly sensitive to this calibration, while the calculated deposition velocities and surface resistances are less sensitive to the calibration, for which sensitivity tests were made (see later in the paper).

The Gill-1012R sonic anemometer was used to provide raw data sets of 3-D-wind speed and sound speed, and to connect the signal of $\mathrm{O}_{3}$ sensor to a $\mathrm{PC}$ at a frequency of $20.695 \mathrm{~Hz}$. The air inlet tube of the fast response ozone sensor was $2 \mathrm{~m}$ long (with a diameter of $3 \mathrm{~mm}$ and a flow rate of approximately $0.6 \mathrm{~L} \mathrm{~min}^{-1}$ ) causing a time lag, which was estimated as the maximum covariance between the vertical wind speed $w$ and $\mathrm{O}_{3}$ concentration using the $15 \mathrm{~min}$ averaging time. The optimum time lag was determined to be $1.59 \mathrm{~s}$, based on the period 9 June 8:30-14:30. The same value was used for the whole measuring campaign.

The turbulent flux of ozone $\left(F_{\mathrm{O}_{3}}\right)$ in $\left[\mu \mathrm{g} \mathrm{m}^{-2} \mathrm{~s}^{-1}\right]$ was calculated for each $15 \mathrm{~min}$ time period as:

$F_{\mathrm{O}_{3}}=-\frac{M_{\mathrm{O}_{3}} p}{R_{*}\left(t_{a}+273.15\right)} \overline{w^{\prime} \chi_{\mathrm{O}_{3}}^{\prime}}$,

where $w^{\prime}$ and $\chi_{\mathrm{O}_{3}}^{\prime}$ are the vertical wind and ozone concentration fluctuations, respectively. $M_{\mathrm{O}_{3}}$ is the molar mass of ozone $\left(48 \mathrm{~g} \mathrm{~mol}^{-1}\right), p$ is the atmospheric pressure (in Pa), $R_{*}$ is the universal gas constant $\left(8.314 \mathrm{~J} \mathrm{~mol}^{-1} \mathrm{~K}^{-1}\right)$, and $t_{a}$ is the air temperature (in ${ }^{\circ} \mathrm{C}$ ). Vertical wind speed and ozone data sets were detrended in order to determine the time series of fluctuations by the moving average technique using a $400 \mathrm{~s}$ time window for the estimation of the mean values (McMillen, 1988; Weidinger et al., 1999; Massman, 2000) and a double rotation was performed on the wind speed to set the averaged vertical and cross-wind direction component of the wind speed to zero (Kaimal and Finnigan, 1994; Mauder and Foken, 2004).

The NOAA fast response ozone sensor is a closed path type sensor. The relatively large time lag $(1.59 \mathrm{~s})$ of this sensor as compared to other sensors (Güsten et al., 1996) with a $0.1 \mathrm{~s}$ time lag, allowed temperature of the sampled air to equilibrate with the sensor temperature. If the trace gas concentrations are determined by closed-path gas analyzers, where the respective trace gas is brought to a common temperature and pressure within the optical bench, then there is no need for a correction associated with the transfer of sensible heat (Grünhage et al., 2000). Therefore fluxes were only corrected for density fluctuations arising from the water vapour flux, but not those arising from the sensible heat flux (WPL correction; Webb et al., 1980). Moreover, the sensor separation correction of Moore (1986) was neglected as the inlet tube was located very close to the Gill path. Finally, the sensible heat flux $H$ was corrected for humidity according to the paper by Schotanus et al. (1983).

The fluxes were filtered to remove periods of poor fetch, which was defined based on Nemitz et al. (2009a). During the integrated field experiment several measuring platforms were settled close to each other. The exact position of each instrument mast in relation to the other masts, mobile laboratories and other obstructions to the fetch was determined and all flux data falling within obstructed sectors were removed from the individual dataset. A further filtering was applied to the flux data (and all derived data) to remove periods when the cumulative normalised footprint (CNF) of the flux (calculated according to Kormann and Meixner, 2001) fell below $67 \%$ contribution from the field. Finally, the "measured" deposition velocity was found as a ratio of measured flux and measured reference ozone concentration.

\section{Ozone deposition modelling}

Measured values of the ozone flux $\left(F_{\mathrm{O}_{3}}\right)$ and deposition velocity $\left(v_{d}\right)$ values were compared with the results of simulations using a big-leaf model. In the model, the total ozone flux $\left(F_{t}\right)$ is calculated as a product of the deposition velocity of ozone $\left(v_{d}\right)$ and the ozone concentration $\left(C_{r}\right)$ at a reference height:

$F_{t}=-v_{d} C_{r}$.

The negative sign represents that the direction of ozone flux is downward. The deposition velocity is defined as the inverse of the sum of the atmospheric and surface resistances, which retard the ozone flux:

$v_{d}=\left(R_{a}+R_{b}+R_{c}\right)^{-1}$,

where $R_{a}$, and $R_{b}$ are the aerodynamic resistance and the quasi-laminar boundary layer resistance, respectively. These terms are calculated using the Monin-Obukhov similarity theory taking into account atmospheric stability (details can be found in Nemitz et al., 2009a). The canopy resistance $\left(R_{c}\right)$ was parameterised with a widely used resistance network:

$R_{c}=$

$\frac{1}{\left(1-W_{s t}\right)\left(R_{s t}+R_{m}\right)^{-1}+\left(R_{\text {cut }}\right)^{-1}+\left(R_{a c}+R_{\text {soil }}\right)^{-1}}$,

where $R_{s t}, R_{m}, R_{\mathrm{cut}}, R_{a c}$ and $R_{\mathrm{soil}}$, and are the stomatal, mesophyll, cuticular, in-canopy aerodynamic and soil resistances, respectively. The fraction of stomatal blocking under wet condition $\left(W_{s t}\right)$ was estimated according to Zhang et 
al. (2003). The stomatal resistance is a key parameter in deposition modelling, which is affected in different degree by both the weather conditions and several plant and soil characteristics (e.g. Mészáros et al., 2009). In this study, stomatal resistance for ozone $\left(R_{s t}\right)$ was calculated from stomatal resistance for water vapour $\left(R_{s b}\right)$ obtained from measured water vapour flux according to Nemitz et al. (2009a):

$$
\frac{R_{s t}}{R_{s b}}=\frac{D_{\mathrm{H}_{2} \mathrm{O}}}{D_{\mathrm{O}_{3}}}=1.65
$$

where $D_{\mathrm{H}_{2} \mathrm{O}}$ and $D_{\mathrm{O}_{3}}$ are the molecular diffusion coefficients for water vapour and ozone, respectively, in air. Nemitz et al. (2009a) derive the time-series of $R_{s b}$ by fitting a parameterisation to $R_{s b}$ calculated from measurements of the latent heat flux $(\lambda E)$ :

$R_{s b}=$

$R_{s b, \min }\left(1+\frac{b}{\max (0.01, S t)}\right) \frac{\mathrm{LAI}_{\mathrm{ref}}}{\mathrm{LAI}}\left(1-b_{e} \times \min (\mathrm{VPD}, 2.5)\right)^{-1}$.

Here $R_{s b}$ is in $\mathrm{s} \mathrm{m}^{-1}, S_{t}$ is solar radiation in $\mathrm{W} \mathrm{m}^{-2}$ and VPD is the vapour pressure deficit in $\mathrm{kPa}$. The fit parameters are $R_{s b, \min }=50 \mathrm{~s} \mathrm{~m}^{-1}, \mathrm{LAI}_{\mathrm{ref}}=5.18, b=200 \mathrm{~m}^{2} \mathrm{~W}^{-1}$ and $b_{e}=0.31 \mathrm{kPa}^{-1}$. In deriving this parameterisation, only data from dry periods were used, to exclude periods where fluxes other than evapotranspiration may have contributed to $\lambda E$.

Because agricultural activities can cause sudden changes in vegetation properties, $R_{\mathrm{cut}}$ and $R_{a c}$ were parameterised as a function of the Leaf Area Index (LAI). Zhang et al. (2003) suggested that cuticle resistance may parameterised differently for dry $\left(R_{\mathrm{cut} d}\right)$ and wet $\left(R_{\mathrm{cut} w}\right)$ canopy:

$R_{\text {cut } d}=\frac{R_{\text {cut } d 0}}{\mathrm{e}^{0.03 \mathrm{RH}_{\mathrm{LAI}}{ }^{1 / 4} u_{*}},}$

$R_{\text {cut } w}=\frac{R_{\text {cut } w 0}}{\operatorname{LAI}^{1 / 2} u_{*}}$

where $\mathrm{RH}$ is the relative humidity (in percentage), $R_{\text {cut } d 0}=4000$, and $R_{\text {cut } w 0}=200$ according to Zhang et al. (2003). LAI varied during the experiment (Fig. 1b) as a result of cutting the grass on the 29 May 2000, when LAI decreased significantly (from around $3 \mathrm{~m}^{2} \mathrm{~m}^{-2}$ to $0.14 \mathrm{~m}^{2} \mathrm{~m}^{-2}$ ). After lifting of cut grass, the vegetation started to grow with a continuous increase of LAI (around 1.5 at the end of the experiment). Friction velocity $\left(u_{*}\right)$ was obtained from consensus micrometeorological dataset of field campaign (Nemitz et al., 2009a). Leaf surface wetness was also continuously measured (Burkhardt et al., 2009) allow to distinguish dry and wet canopy.

The in-canopy aerodynamic resistance $\left(R_{a c}\right)$ was derived from the in-canopy measurements of turbulence presented by Nemitz et al. (2009b). A turbulent resistance can be calculated as the integral over the inverse eddy diffusivity $\left(K_{M}\right)$, which in turn can be linked to the standard deviation of $w\left(\sigma_{w}\right)$ and the Lagrangian time-scale $\left(\tau_{L}\right)$ (Nemitz et al., 2001):

$$
\int_{0}^{R_{a c}=}\left(K_{M}(z)\right)^{-1} d z=\int_{0}^{d+z_{0}}\left(\sigma_{w}^{2}(z) \tau_{L}(z)\right)^{-1} d z .
$$

Here we use the formulation of Leuning (2000) for $\tau_{L}(z)$ while the parameterisation of $\sigma_{w}$ is based on measurements of in-canopy turbulence during period 1 (Nemitz et al., 2009 b), corrected for changes in canopy height. This combination was found to be consistent with measurements of the eddy-diffusivity based on a $R n$ tracer technique. The combination of these two parameterisations was evaluated for different canopy heights $\left(h_{c}\right)$ to derive the polynomial fit:

$R_{a c}=$

$\frac{83557 h_{c}^{5}-168399 h_{c}^{4}+102670 h_{c}^{3}-16174 h_{c}^{2}+2388.5 h_{c}^{-} 46.404}{u_{*}}$,

where $R_{a c}$ is in $\mathrm{s} \mathrm{m}^{-1}, u_{*}$ is in $\mathrm{m} \mathrm{s}^{-1}$ and $h_{c}$ is in $\mathrm{m}$. It should be noted that our measurement evidence leads to a parameterisation with a significantly stronger dependence on $h_{c}$ than some previous formulations (e.g. Zhang et al., 2003), with typical daytime values between 5000 and $10000 \mathrm{~s} \mathrm{~m}^{-1}$ before the cut and $500 \mathrm{~s} \mathrm{~m}^{-1}$ after the cut.

Based on Massman (2004), wet soils are associated with relatively greater resistances for $\mathrm{O}_{3}$ deposition than dry soils (Massman suggested $R_{g}=500 \mathrm{~s} \mathrm{~m}^{-1}$ for wet case). Soil NO emissions may also affect the value of $R_{\text {soil }}$ (Pilegaard, 2001), however there is no sufficient information about this relationship. Therefore $R_{\text {soil }}$ was parameterised here with a simple linear function considering the effect of soil water availability:

$R_{g}=R_{g 0}+300 \mathrm{~s} \mathrm{~m}^{-1} \frac{\theta}{\theta_{f}}$,

where $R_{g 0}=200 \mathrm{~s} \mathrm{~m}^{-1}, \theta$ is the soil water content (was measured during the campaign - Fig. 1) and $\theta_{f}$ is the soil water content at field capacity (value of 0.19 for sand soil was used for this site based on Sutton et al., 2009a).

Considering that the flux is constant between the reference height and the top of the canopy, the total ozone flux can be written as follows:

$F_{t}=-C_{r}\left(R_{a}+R_{b}+R_{c}\right)^{-1}=-C_{c} R_{c}^{-1}$,

where $C_{r}$ is the concentration at the measuring height, and $C_{c}$ is the concentration at the top of the canopy, defined as a level, where the flux divides into stomatal $\left(F_{s t}\right)$ and nonstomatal $\left(F_{n s}\right)$ part (Cieslik, 2004):

$F_{t}=F_{s t}+F_{n s}=-C_{c} R_{s t}^{-1}-C_{c} R_{n s}^{-1}$, 

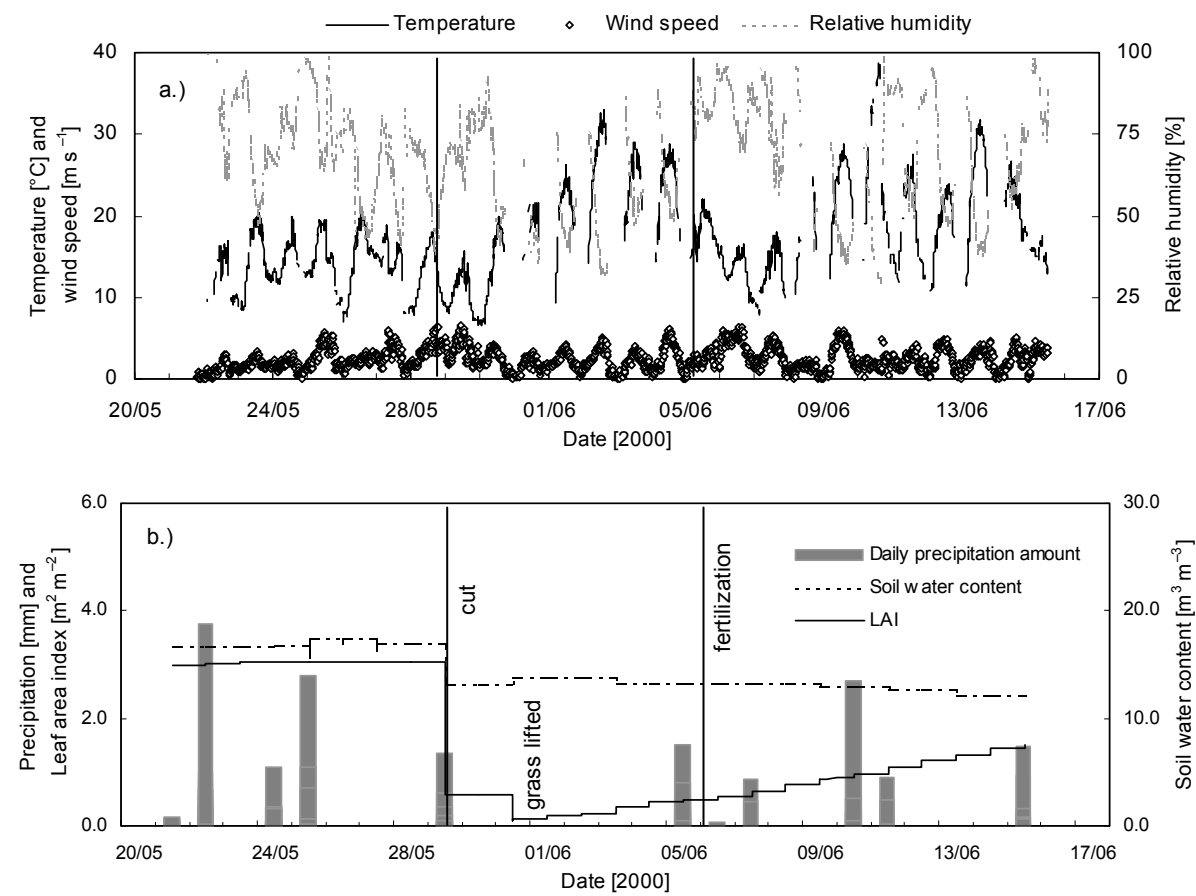

Fig. 1. Meteorological conditions and leaf area index (LAI) during the campaign: (a) air temperature, wind speed and relative humidity measured $2 \mathrm{~m}$ above the vegetation, (b) daily amount of precipitation, root-zone soil water content and LAI. The field was cut on 29 May, the grass was lifted on 31 May and the grassland was fertilized on 6 June 2000.

where $R_{s t}$ is the stomatal resistance and $R_{n s}$ is the nonstomatal resistance covering all deposition pathways but stomatal. According to Eqs. (13) and (14), the stomatal flux is calculated separately:

$F_{s t}=-C_{c} R_{s t}^{-1}=-\frac{R_{c}}{\left(R_{a}+R_{b}+R_{c}\right) R_{s t}} C_{r}$,

therefore:

$F_{s t}=F_{t} R_{c} R_{s t}^{-1}$.

\section{Results and discussion}

\subsection{Meteorological conditions}

Figure 1 shows the evolution of meteorological conditions, soil water content and canopy structure during the experiment. The weather was variable: showers were frequent and air temperature ranged from less than $10^{\circ} \mathrm{C}$ to more than $30^{\circ} \mathrm{C}$, while wind speed ranged from 0 to more than $5 \mathrm{~m} \mathrm{~s}^{-1}$. The average temperatures in the first, second and third measuring period were $13.9,19.5$ and $18.9^{\circ} \mathrm{C}$, respectively, while there were no significant changes in average wind speed (around $2.5 \mathrm{~m} \mathrm{~s}^{-1}$ in each period). The average relative humidity was $70 \%$ both in the first and the third period, while the second was the driest period $(61 \%)$. The soil water content in the upper $0.6 \mathrm{~m}$ soil layer varied from $0.17 \mathrm{~m}^{3} \mathrm{~m}^{-3}$ at the beginning of the experiment to $0.12 \mathrm{~m}^{3} \mathrm{~m}^{-3}$ at the end of the experiment. Despite the rain events, the soil water content decreased during the measuring period because of higher temperature and higher evapotranspiration in the second and third part of measurements. The canopy LAI was larger than $3 \mathrm{~m}^{2} \mathrm{~m}^{-2}$ at the beginning of the experiment and decreased to less than $0.14 \mathrm{~m}^{2} \mathrm{~m}^{-2}$ after the cut, before the canopy started re-growing.

\subsection{Ozone concentration, flux and deposition velocity}

The variation in time of ozone concentrations during the campaign can be seen in Fig. 2a. Ozone concentrations were significantly larger after the cut. Before the cut (29 May 2000 ), the daily maximum $\chi_{\mathrm{O}_{3}}$ was around $40 \mathrm{ppb}$, while after the cut concentrations often exceeded this level. However, these differences cease to be significant after concentrations have been filtered for periods, for which the flux data are deemed reliable according to filtering criteria described in Sect. 2.3. Figure $2 b$ presents the time series of the measured (and modelled, see below) $\mathrm{O}_{3}$ fluxes. The daily maximum of measured ozone fluxes varied from below 0.2 to more than $0.6 \mu \mathrm{g} \mathrm{m}^{-2} \mathrm{~s}^{-1}$. The highest flux $\left(0.65 \mu \mathrm{g} \mathrm{m}^{-2} \mathrm{~s}^{-1}\right)$ was measured on 23 May, around noon. Both measured and modelled fluxes were lower in the second and third periods than before the cut. Similarly to the flux values, the highest deposition velocities were found on 23 May (with a maximum of $1.06 \mathrm{~cm} \mathrm{~s}^{-1}$ ) as can be seen in Fig. 2c. Except for a few cases, daytime deposition velocity was lower after the cut. A 

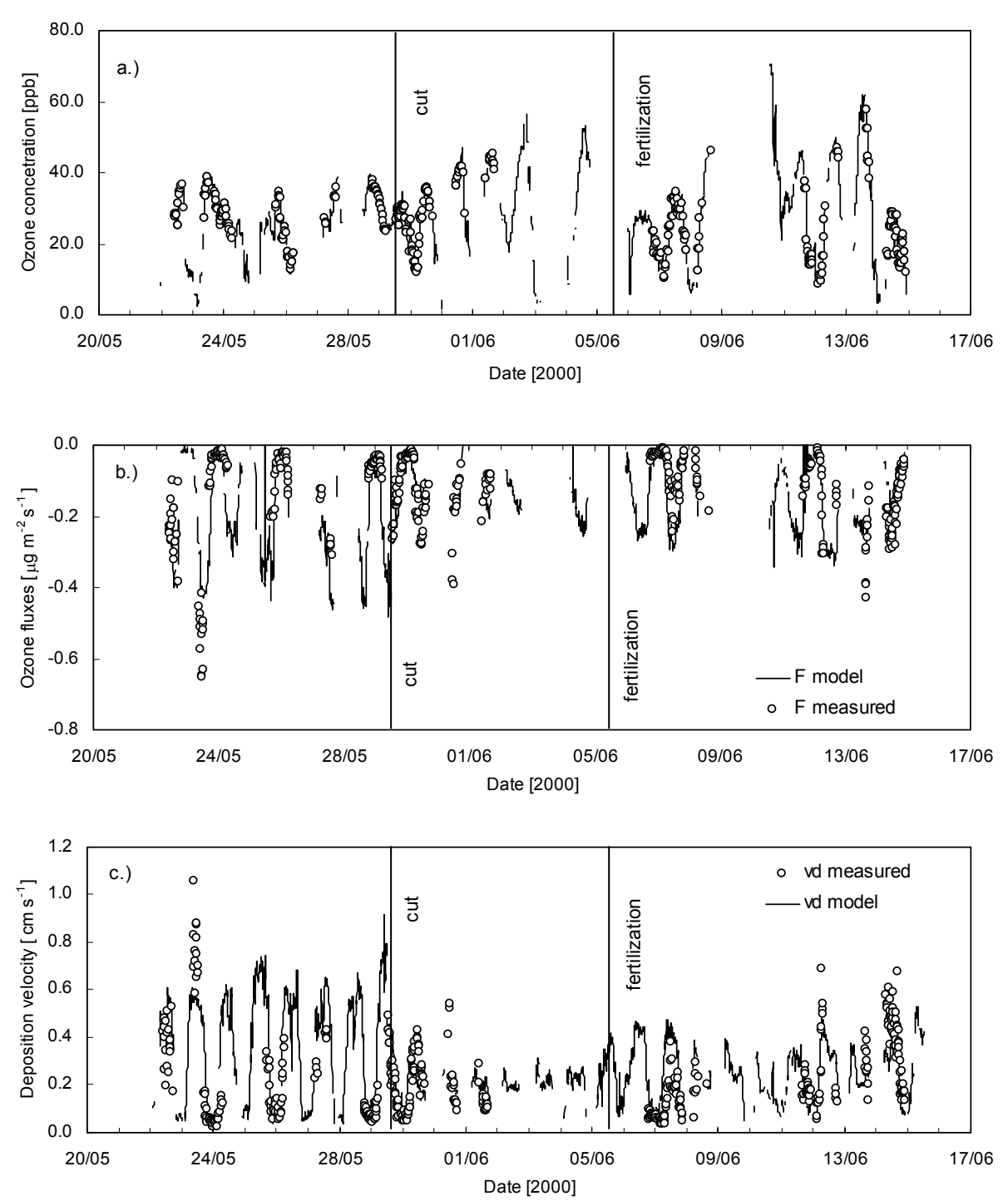

Fig. 2. (a) Ozone concentration during the campaign, measured at Broitzem urban background station (5 km from the flux site): symbols represent values, where flux measurements were available, (b) measured and modelled ozone fluxes during the campaign and (c) measured and modelled ozone deposition velocity during the campaign.

small decrease of $v_{d}$ can be seen during the six days following fertilization, a period of very large $\mathrm{NH}_{3}$ fluxes (Milford et al., 2009), but higher values were found at the end of the third period. In general, measured ozone deposition velocities over grassland are within the range of those found in the literature (e.g. Padro, 1996; Meyers et al., 1998; Zhang et al., 2002a; Coyle, 2005).

A clearer picture of the differences between the three periods (before the cut, after the cut and re-growth after fertilization) emerges, if average diurnal cycles of ozone concentrations, fluxes and deposition velocities are considered. These are shown in Fig. 3, with the statistics of the measured deposition fluxes for the three periods provided in Table 1. Diurnal variations of ozone concentration were more pronounced in the second and third periods, while the lowest variability and highest night-time values found in the first period (Fig. 3a). The daily patterns of measured deposition velocities (Fig. 3c) demonstrate that after the cut the daytime average of the deposition velocity decreased from $0.44 \mathrm{~cm} \mathrm{~s}^{-1}$ to $0.26 \mathrm{~cm} \mathrm{~s}^{-1}$. During the third period the average daytime deposition velocity was $0.32 \mathrm{~cm} \mathrm{~s}^{-1}$. Average night-time deposition velocities showed a different pattern: average $v_{d}$ increased from $0.07 \mathrm{~cm} \mathrm{~s}^{-1}$ before the cut, to 0.08 after the cut and to $0.11 \mathrm{~cm} \mathrm{~s}^{-1}$ after fertilization.

The daily pattern of measured ozone fluxes (Fig. 3b) shows that highest daytime values occurred in the first period (with a maximum of around $0.4 \mu \mathrm{g} \mathrm{m}^{-2} \mathrm{~s}^{-1}$ in late morning); the flux decreased after cut and increased again slightly in the 

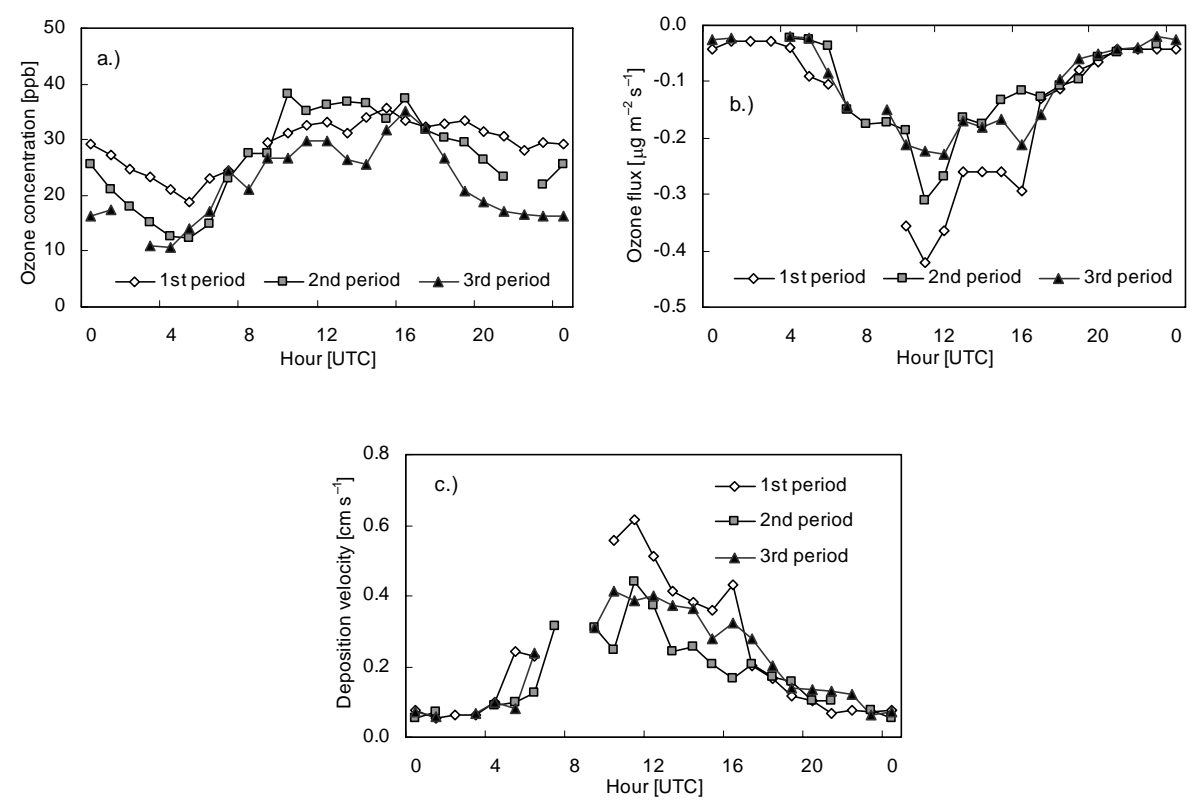

Fig. 3. Average daily courses of (a) ozone concentration, (b) measured ozone fluxes and (c) measured deposition velocities during the three periods: 1st period: 20 May 2000-29 May 2000 (pre cut), 2nd period: 29 May 2000-5 June 2000 (post cut, pre fertilization), 3rd period: 5 June 2000-15 June 2000 (post fertilization).

third period. Because night-time $\mathrm{O}_{3}$ concentration inreased at a similar rate as $v_{d}$ decreased, the night-time flux remained fairly constant over the three periods. Of the parameters presented here, $v_{d}$ (and the resistances derived thereof) are the most robust as they are very only slightly affected by any potential uncertainties involved in using an ozone concentration from $5 \mathrm{~km}$ away to turn relative fluxes into absolute values. The uncertainty in the measured concentration propagates to cause an error in the flux of similar magnitude. However, the uncertainty in the concentration affects the deposition velocity and inferred canopy resistances much less (Fig. 4). For example, a difference of $10 \%$ in measured concentration causes around $11 \%$ difference in measured flux. At the same time, the differences are within $2 \%$ in the case of both the deposition velocity and the canopy resistance. In addition, the flux is also controlled by the air concentrations, while $v_{d}$ is a better descriptor of the deposition processes governed by the canopy, but also constrained by atmospheric turbulence.

Overall, the decrease in $v_{d}$ (and thus in the flux) after the cut was smaller than may be expected due to the large reduction in LAI, which should have decreased both stomatal and cuticular uptake dramatically. Indeed, the comparison of the average diurnal cycles in stomatal conductance $\left(g_{s t}=1 / R_{s t}\right.$, derived from the parameterisation based on latent heat flux measurements) shows a decrease by a factor of four to five after the cut (Fig. 5a). It should be noted that this was not just a response to LAI, but during the period of 1-4 June in particular, high VPD (indicating draught conditions) significantly decreased $g_{s t}$ further (Nemitz et al., 2009a).

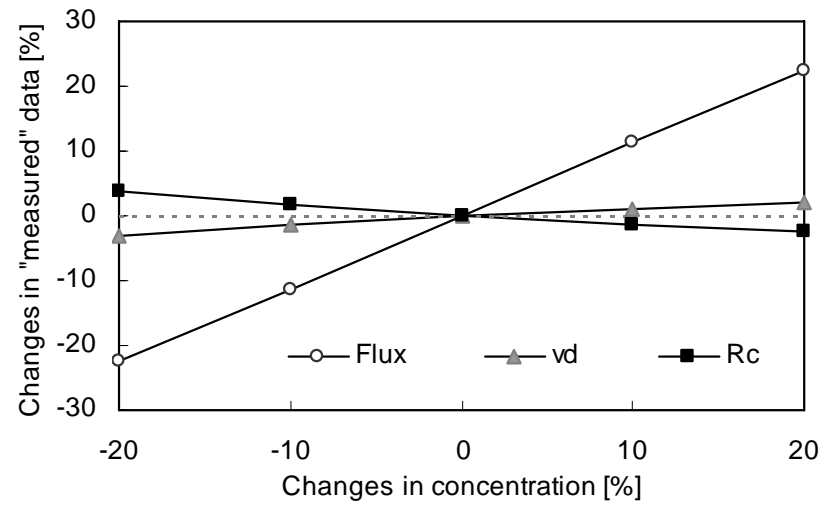

Fig. 4. Average changes of ozone flux, deposition velocity and canopy resistance as a function of changes in measured ozone concentration.

The turbulence (as expressed through the friction velocity $u_{*}$ ) was similar between periods (Fig. $5 \mathrm{~b}$ ), and thus the relative small decrease in $v_{d}$ was not the effect of compensating influences in turbulence.

By contrast, the reason for the small change in $v_{d}$ (and flux) appears to have been the behaviour of the non-stomatal flux $\left(F_{n s}\right.$, Fig. $\left.5 c\right)$, which did not decrease significantly and sometimes increased in the afternoon in spite of the decrease in LAI. As a sensitivity study, $F_{n s}$ was also derived using an alternative estimate of $R_{s b}$ (Fig. 5d) provided by Nemitz et al. (2009a), based on somewhat larger latent heat fluxes, to explore the implications $\lambda E$ flux losses may have for this 
Table 1. Statistics of (a) measured ozone fluxes, (b) modelled ozone fluxes, (c) modelled stomatal ozone fluxes (d) modelled ozone deposition velocity for three periods: 1st: 20 May 2000-29 May 2000 (pre cut), 2nd period: 29 May 2000-5 May 2000 (post cut, pre fertilization), 3rd period: 5 June 2000-15 June 2000 (post fertilization). Daytime was defined as time between 06:00 and 17:00 UTC, and night-time is between 20:00 and 04:00 UTC. Negative flux values represent deposition.

\begin{tabular}{|c|c|c|c|c|c|c|c|c|c|}
\hline & \multicolumn{3}{|c|}{ 1st period } & \multicolumn{3}{|c|}{ 2nd period } & \multicolumn{3}{|c|}{ 3rd period } \\
\hline & whole day & daytime & night-time & whole day & daytime & night-time & whole day & daytime & night-time \\
\hline \multicolumn{10}{|l|}{$\begin{array}{l}\text { (a) measured } \mathrm{O}_{3} \\
\text { fluxes } \\
{\left[\mu \mathrm{g} \mathrm{m}^{-2} \mathrm{~s}^{-1}\right]}\end{array}$} \\
\hline$N$ (15-min periods) & 142 & 50 & 70 & 103 & 69 & 23 & 176 & 98 & 48 \\
\hline Average & -0.13 & -0.28 & -0.04 & -0.13 & -0.17 & -0.03 & -0.12 & -0.17 & -0.04 \\
\hline Median & -0.06 & -0.25 & -0.04 & -0.12 & -0.15 & -0.03 & -0.09 & -0.14 & -0.03 \\
\hline Standard dev. & 0.15 & 0.17 & 0.01 & 0.08 & 0.07 & 0.02 & 0.08 & 0.09 & 0.02 \\
\hline Minimum & -0.01 & -0.05 & -0.01 & -0.01 & -0.04 & -0.01 & -0.01 & -0.02 & -0.01 \\
\hline Maximum & -0.65 & -0.65 & -0.08 & -0.39 & -0.39 & -0.07 & -0.43 & -0.43 & -0.07 \\
\hline \multicolumn{10}{|l|}{$\begin{array}{l}\text { (b) modelled } \mathrm{O}_{3} \\
\text { fluxes } \\
{\left[\mu \mathrm{g} \mathrm{m}^{-2} \mathrm{~s}^{-1}\right]}\end{array}$} \\
\hline Average & -0.16 & -0.32 & -0.06 & -0.12 & -0.15 & -0.05 & -0.13 & -0.19 & -0.03 \\
\hline Median & -0.10 & -0.33 & -0.04 & -0.13 & -0.15 & -0.04 & -0.11 & -0.19 & -0.03 \\
\hline Standard dev. & 0.14 & 0.09 & 0.04 & 0.06 & 0.04 & 0.01 & 0.09 & 0.06 & 0.01 \\
\hline Minimum & -0.02 & -0.17 & -0.02 & -0.00 & -0.00 & -0.03 & -0.02 & -0.05 & -0.02 \\
\hline Maximum & -0.46 & -0.46 & -0.19 & -0.27 & -0.27 & -0.08 & -0.30 & -0.30 & -0.06 \\
\hline \multicolumn{10}{|l|}{$\begin{array}{l}\text { (c) } \mathrm{O}_{3} \text { deposition } \\
\text { velocity }\left[\mathrm{cm} \mathrm{s}^{-1}\right]\end{array}$} \\
\hline Average & 0.22 & 0.44 & 0.07 & 0.21 & 0.26 & 0.08 & 0.23 & 0.32 & 0.11 \\
\hline Median & 0.11 & 0.40 & 0.07 & 0.19 & 0.24 & 0.07 & 0.19 & 0.28 & 0.10 \\
\hline Standard dev. & 0.22 & 0.23 & 0.03 & 0.12 & 0.11 & 0.03 & 0.16 & 0.16 & 0.05 \\
\hline Minimum & 0.03 & 0.11 & 0.03 & 0.05 & 0.09 & 0.05 & 0.03 & 0.04 & 0.04 \\
\hline Maximum & 1.06 & 1.06 & 0.14 & 0.54 & 0.54 & 0.13 & 0.69 & 0.69 & 0.21 \\
\hline \multicolumn{10}{|l|}{$\begin{array}{l}\text { (d) modelled } \mathrm{O}_{3} \\
\text { deposition velocity } \\
{\left[\mathrm{cm} \mathrm{s}^{-1} \text { ] }\right.}\end{array}$} \\
\hline Average & 0.28 & 0.52 & 0.11 & 0.21 & 0.24 & 0.12 & 0.25 & 0.35 & 0.11 \\
\hline Median & 0.20 & 0.55 & 0.07 & 0.19 & 0.21 & 0.09 & 0.26 & 0.35 & 0.10 \\
\hline Standard dev. & 0.21 & 0.08 & 0.09 & 0.09 & 0.08 & 0.07 & 0.13 & 0.07 & 0.04 \\
\hline Minimum & 0.04 & 0.33 & 0.04 & 0.06 & 0.13 & 0.30 & 0.04 & 0.14 & 0.04 \\
\hline Maximum & 0.64 & 0.64 & 0.45 & 0.46 & 0.46 & 0.07 & 0.48 & 0.48 & 0.26 \\
\hline
\end{tabular}

analysis. As can be seen from the similarity of Fig. $5 \mathrm{c}$ and $\mathrm{d}$, the quantification of $F_{n s}$ is robust. There are several processes that could have stimulated non-stomatal $\mathrm{O}_{3}$ destruction at the surface after the cut:

- As mentioned above, in some studies, non-stomatal $\mathrm{O}_{3}$ deposition is attributed to gas-phase destruction by reaction with biogenic VOCs. At a Californian pine forest an increase in $\mathrm{O}_{3}$ deposition was observed after thinning (mastication), and this was attributed to increased emissions of monoterpenes (and presumably other reactive BVOCs) after the thinning event (Goldstein et al., 2004). Grass cutting is known to release wound compounds such as leaf alcohols (e.g. Karl et al., 2001). A limited set of BVOCs was measured during the campaign and found not to increase after the cut (Nemitz 

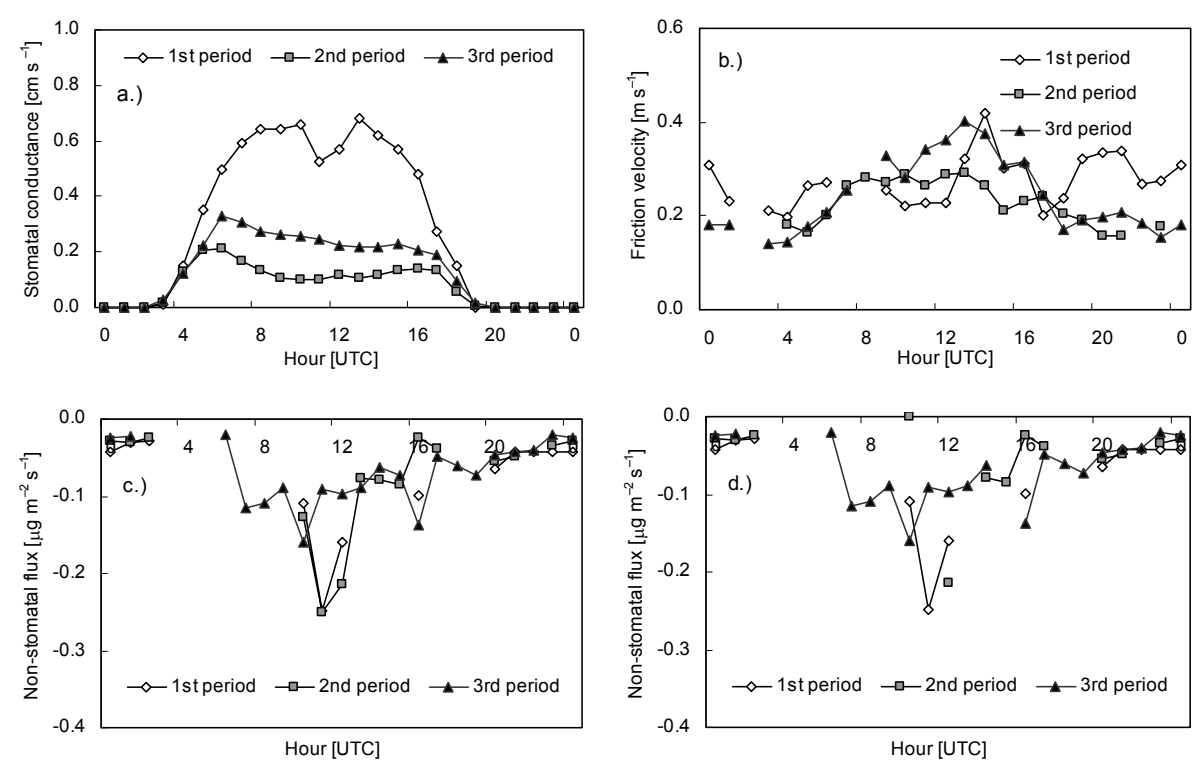

Fig. 5. Average daily courses of (a) stomatal conductance $\left(g_{s t}\right)$, (b) friction velocity $\left(u_{*}\right)$, (c) non-stomatal flux $\left(R_{n s}\right)$ during the three periods based on the standard estimate of $R_{s t}$, and (d) the same based on an alternative estimate $R_{s b}$.

et al., 2009b), but these were selected to study the importance for cutting emissions on aerosol production rather than $\mathrm{O}_{3}$ reactivity, and they did not include light leaf alcohols. Significant quantities of wound compounds are therefore likely to have been emitted for the first few hours after the cut, and may well be efficient in reacting with ozone. However, these emissions are unlikely to explain sustained high $\mathrm{O}_{3}$ deposition velocities for the remainder of the period.

- Ozone is destroyed by reactions with NO emitted by soils (e.g. Pilegaard, 2001). Fertilization is known to favour NO emissions from soils by nitrification, or denitrification. Although the NO flux was not measured during this campaign nitrification should have occurred following fertilization as indicated by the soil $\mathrm{NO}_{3}^{-}$concentrations build up following fertilization (Sutton et al., 2009b). However, the measured $\mathrm{O}_{3}$ flux seems to have decreased slightly immediately following fertilization (7 and 8 June - see Fig. 2), instead of increasing as would be expected if an NO flux had occurred (as $\mathrm{NO}$ would consume $\mathrm{O}_{3}$ ). This can be explained by the increased diffusivity and hence decreased transfer time of $\mathrm{O}_{3}$ within the canopy following cutting, which will leave less time for the $\mathrm{NO}-\mathrm{O}_{3}$ reaction to occur. Thus, the time-trend of $v_{d}$ after the cut shows the wrong time evolution to be caused by destruction through NO emissions.

- The soil became more aerodynamically accessible to deposition as the in-canopy resistance decreased. If the soil provided a more efficient (per area) $\mathrm{O}_{3}$ sink than

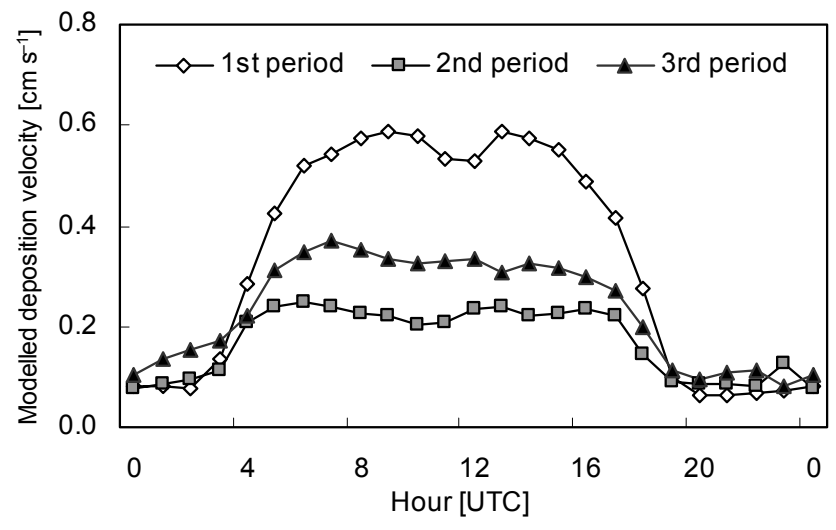

Fig. 6. Average daily courses of modelled deposition velocity in the three periods.

leaf surfaces, the increase in the cuticular resistance due to the removal of leaf area may well have been compensated for by the reduction in the in-canopy transport resistance.

- There is growing evidence that the destruction of ozone on leaf surfaces depends on both leaf moisture and temperature (Fowler et al., 2001; Zhang et al., 2002b; Coyle, 2005; Mikkelsen et al., 2004; Altimir et al., 2006). Due to the lack of transpiring vegetation after the cut, the Bowen ratio increased slightly, resulting in an overall increase in the canopy temperature during the day. Also, after the cut, senescent plant material was exposed, which was not transpiring at all and therefore heated up during the day, to temperatures up to $10^{\circ} \mathrm{C}$ 

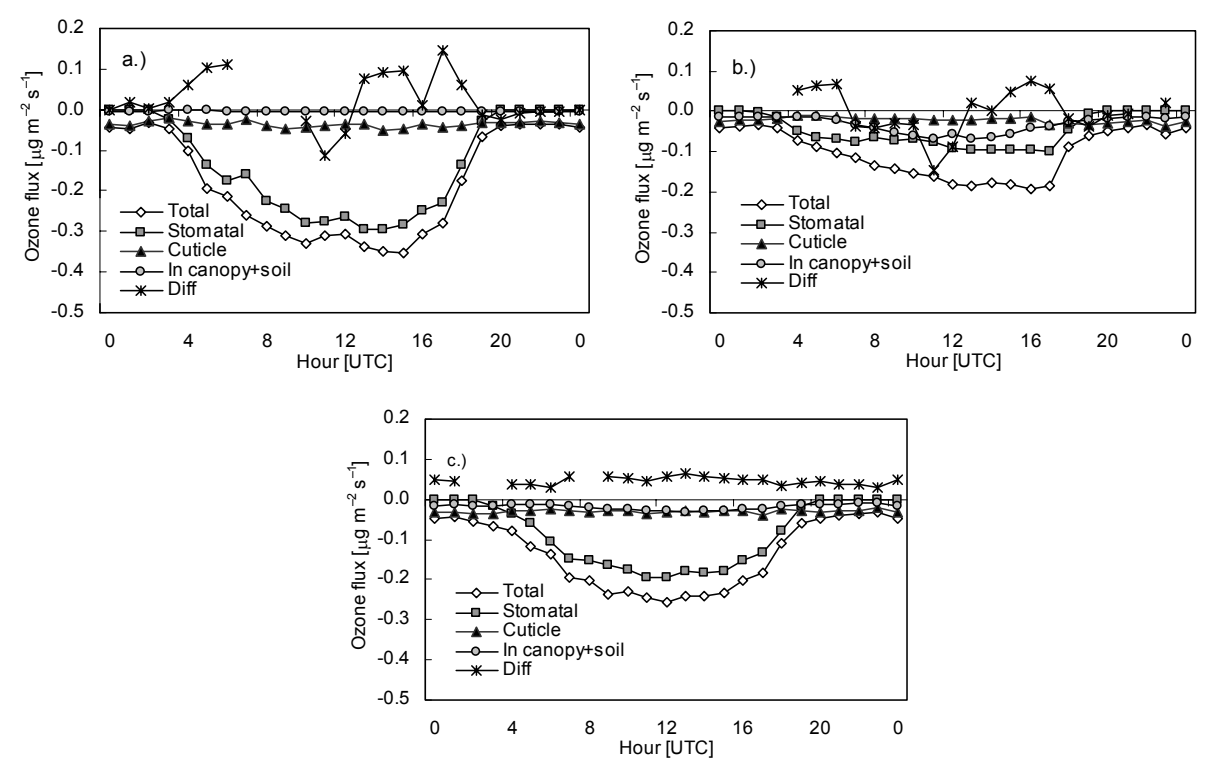

Fig. 7. Average daily courses of modelled ozone fluxes (total and part of stomatal, cuticle, in canopy+soil and differences of measured minus modelled fluxes) for three periods: (a) 1st period: 20 May 2000-29 May 2000 (pre cut), (b) 2nd period: 29 May 2000-5 May 2000 (post cut, pre fertilization), (c) 3rd period: 5 May 2000-15 May 2000 (post fertilization).

above that of green, transpiring vegetation (Nemitz et al., 2009a). This senescent material was found to be the source of $\mathrm{NH}_{3}$ emissions following the cut (prior to fertilization; e.g. Sutton et al., 2009b) and may have increased the non-stomatal $\mathrm{O}_{3}$ sink due to the temperature effect and by emitting further VOCs.

Few measurements of $\mathrm{O}_{3}$ fluxes before and after grass cutting have been reported in the literature, but the observation of limited reduction in $v_{d}$ after grass cutting is not unique. Coyle (2005) reported long-term measurements of $\mathrm{O}_{3}$ fluxes on a managed grassland in S Scotland, which included five cuts for silage. The cut led to a clear reduction in flux (and increase in $R_{c}$ ) during three events, a small reduction during one event and no change during the first cut investigated. The author suggests BVOC chemistry as a potential reason for the lack of change during some cuts, but variability between cuts could not be fully explained.

\subsection{Model results}

The model provides the means to explore the different component fluxes further (including the deposition to soil), and to extrapolate the measurements to provide better temporal coverage and to develop a new parameterisation capable of reproducing the measurements.

Modelled flux and deposition velocity of ozone can be seen in Fig. $2 b$ and $c$ for the whole campaign. The average diurnal pattern of modelled deposition velocities (Fig. 6) shows that the modelled daytime values compare reasonably well with the measured values, but prior to the cut $v_{d}$ was overestimated by the model (with the exception of 23 May), while after the cut $v_{d}$ tended to be underestimated by the model. Thus, a somewhat greater variability of modelled values between periods was obtained, with average daytime values of modelled deposition velocity of $0.52,0.24$, and $0.35 \mathrm{~cm} \mathrm{~s}^{-1}$ in the first, second and third period, respectively, compared with measurement derived values of $0.44,0.26$ and $0.32 \mathrm{~cm} \mathrm{~s}^{-1}$ (see Table 1). Thus the model overestimates $v_{d}$ to the long grass, possibly due to an underestimation in the cuticular resistance, and overestimates the influence of the cut, which is nevertheless smaller than expected based on the change in LAI alone.

At night, the model overestimates deposition velocities in the first and second period. Average modelled night-time deposition velocities were $0.11,0.12$ and $0.11 \mathrm{~cm} \mathrm{~s}^{-1}$ for the first, second and third period, respectively. This overestimation may be due to the parameterisation of cuticle $\left(R_{\text {cut }}\right)$ and in-canopy resistance $\left(R_{a c}\right)$, which does not account for the effects of atmospheric stability. Based on model simulations, the total flux was also partitioned into stomatal and non-stomatal parts. Figure 7 shows the average daily courses of modelled fluxes. Model calculations show a higher decrease after the cut with a major change in the comparative magnitudes of the component fluxes. Before the cut, the daytime fluxes were dominated ( $>80 \%)$ by stomatal exchange, while night-time fluxes were due to cuticular deposition and soil exchange was unimportant (Table 2). Both stomatal and cuticular pathways decreased after the reduction of LAI in the second period. However, the contribution from deposition to soil increased after the cut, due to the reduction of $R_{a c}$ and $R_{g}$, more than compensating for the reduction in cuticular flux. The in-canopy resistance was lower after the 
Table 2. Fractional ozone fluxes (in \%) to stomata, cuticle and in-canopy+soil. Average modelled daytime and night-time values. Night-time was defined as a period, when solar radiation was equal to zero.

\begin{tabular}{lrrrrrr}
\hline & \multicolumn{1}{c}{$\begin{array}{c}\text { 1st period } \\
\text { (pre-cut) }\end{array}$} & $\begin{array}{c}\text { 2nd period } \\
\text { (after cut) }\end{array}$ & \multicolumn{2}{c}{$\begin{array}{c}\text { 3rd period } \\
\text { (regrowth after } \\
\text { fertilization) }\end{array}$} \\
\cline { 2 - 7 } & daytime & night-time & daytime & night-time & daytime & night-time \\
\hline$F_{\text {st }}$ & 84 & 0 & 55 & 0 & 75 & 0 \\
$F_{\text {cut }}$ & 14 & 87 & 12 & 65 & 14 & 71 \\
$F_{\text {in-canopy+soil }}$ & 2 & 13 & 33 & 35 & 11 & 29 \\
\hline
\end{tabular}

cut because of lower LAI, while the lower soil resistances reflect the drier soil after the cut (see Fig. 1). Thus the accessibility of the soil partially compensated for the reduction in LAI. After fertilization, during re-growth, stomatal deposition again dominated the deposition, reaching $80 \%$ of the pre-cut value, averaged over the second week after the cut.

Figure $7 \mathrm{a}$ to $\mathrm{c}$ also includes the difference of measured minus modelled flux, as the deposition flux component that is not reproduced by the model (if negative) or over-prediction of the model (if positive). Bearing in mind the uncertainties in the measurements, the comparison nevertheless suggests that the over-prediction of the deposition during period 1 mainly occurs during most of the day, except during midday, when the model underestimates the deposition flux. More significant, after the cut the sink that is missing in the model also appears to peak at midday, when biogenic emissions and chemical interactions would be expected to be largest. During period 3 , the model very slightly overpredicts deposition throughout the day.

\section{Conclusion}

During the GRAMINAE joint field campaign ozone flux measurements over intensively managed grassland were carried out semi-continuously for one month, which supported an analysis of the effects of agricultural activities (cut and fertilization) on ozone deposition processes. Because of the application of stringent filtering criteria to maximise quality control, only a limited set of results was available for these analyses. However, the results obtained from both measurements and modelling contribute to the understanding of the soil-vegetation-atmosphere interactions. In this paper we have analysed the results of ozone flux measurements by eddy covariance-method, and model estimations with a detailed deposition model.

Results of ozone flux measurements indicated that daytime ozone flux decreased after cut, but to a smaller extent than would be expected due to the drastic $(1 / 20)$ reduction of LAI, which decreased both stomatal and cuticular uptake. The measurement derived parameterisations indicate that the decrease in LAI by the cut was reflected in a decrease in stomatal conductance, which was further exacerbated by limitations in soil water content (as parameterised through the vapour pressure deficit), but it recovered to $80 \%$ of its original value 7 days after the cut. The cuticular pathway decreased after the cut, but to a smaller degree than the stomatal flux. At the same time, with decreasing vegetation height and LAI and increasing soil porosity, due to drier conditions, the ground flux is estimated to have increased. The increase in the ground flux explains why deposition rates did not decrease after the cut as much as would have been expected on the basis of the reduction in LAI. This suggests that a further process must have increased non-stomatal destruction of ozone after the cut.

Potential processes that could have increased non-stomatal ozone destruction at the surface include $\mathrm{O}_{3}$ reaction with biogenic emissions of volatile organic compounds (VOC) or soil NO. VOC emissions may have been stimulated by the cut from the plant wounds, but also the exposed litter, especially under the very warm and dry conditions during this period. In addition, after the fertilization $\mathrm{NO}$ emissions are assumed to have increased (inferred by greatly increased soil nitrate levels) providing a further (chemical) sink for ozone. However, due to the lower canopy and therefore the faster transfer time, there would also have been less time for the $\mathrm{NO}-\mathrm{O}_{3}$ reaction. Warm conditions after the cut may also have promoted the destruction of ozone on leaf surfaces, a dependency that is consistent with the recent literature, but not yet included in current parameterisations of cuticular uptake.

In summary, ozone fluxes and deposition velocities were determined during the measuring period in different environmental conditions and agricultural activities. The changes of ozone flux and deposition velocity after the cut are attributed to: i) the very low vegetation with decreased stomatal and cuticular uptake, and at the same time increased importance of soil sinks and chemical reactions, ii) the moderately low vegetation combined with potential VOC and soil NO emission after fertilization. These complex, highly nonlinear effects reveal the importance of canopy structure and non-stomatal pathways on $\mathrm{O}_{3}$ fluxes. 
Acknowledgements. Investigations were co-ordinated and supported by CEH (Centre for Ecology and Hydrology, UK) under the complementary contract of IC20-CT98-0118 to the EU-IV Framework Contract of ENV4-CT98-0722 (co-ordinator: Mark A. Sutton, CEH Edinburgh). Final synthesis of this paper was conducted as part of the NitroEurope Integrated Project. The authors acknowledge the support of OTKA grant K68253 and the Öveges József Fellowship.

Edited by: M. Sutton

\section{References}

Altimir, N., Kolari, P., Tuovinen, J.-P., Vesala, T., Bäck, J., Suni, T., Kulmala, M., and Hari, P.: Foliage surface ozone deposition: a role for surface moisture?, Biogeosciences, 3, 209-228, 2006, http://www.biogeosciences.net/3/209/2006/.

Ashmore, M. R., Büker, P., Emberson, L. D., Terry, A. C., and Toet, S.: Modelling stomatal ozone flux and deposition to grassland communities across Europe, Environ. Pollut. 146, 659-670, 2007.

Bassin, S., Volk, M., and Fuhrer, J.: Factors affecting the ozone sensitivity of temperate European grasslands: an overview, Environ. Pollut., 146(3), 678-691, 2007.

Burkhardt, J., Flechard, C. R., Gresens, F., Mattsson, M., Jongejan, P. A. C., Erisman, J. W., Weidinger, T., Meszaros, R., Nemitz, E., and Sutton, M. A.: Modelling the dynamic chemical interactions of atmospheric ammonia with leaf surface wetness in a managed grassland canopy, Biogeosciences, 6, 67-83, 2009,

http://www.biogeosciences.net/6/67/2009/.

Cape, J. N., Hamilton, R., and Heal, M. R.: Reactive uptake of ozone at simulated leaf surfaces, Atmos. Environ., 43, 11161123, 2009.

Cieslik, S. A.: Ozone uptake by varios surface types: a comparison between dose and exposure, Atmos. Environ., 38, 2409-2420, 2004.

Coyle, M.: The gaseous exchange of ozone at terrestrial surfaces: non-stomatal deposition to grassland, Ph.D. thesis, University of Edinburgh, 311 pp., 2005.

Crutzen, P. J., Lawrence, M. G., and Pöschl, U.: On the background photochemistry of tropospheric ozone, Tellus Series A - Dynamic Meteorology and Oceanography, 51, 123-146, 1999.

Diem, J. E.: A critical examination of ozone mapping from a spatial-scale perspective, Environ. Pollut., 125, 369-383, 2003.

Duyzer, J., Weststrate, H., Verhagen, H., Deinum, G., and Baak, J.: Measurements of dry deposition fluxes of nitrogen compounds and ozone, in: Biosphere-atmosphere exchange of pollutants and trace substances: Experimental and Theoretical Studies of Biogenic Emissions and Pollutant Deposition, edited by: Slanina, S., Springer, 4, 244-250, 1997.

Emberson, L.: Air pollution impacts on crops and forests: An introduction. in: Air pollution impacts on crops and forests. A global assessment, edited by: Emberson, L., Ashmore, M., and Murray, F., Imperial College Press, London, 4, 3-29, 2003.

Fowler, D., Flechard, C., Cape, J. N., Storeton-West, R. L., and Coyle, M.: Measurements of ozone deposition to vegetation quantifying the flux, the stomatal and non-stomatal components, Water Air Soil Pollut., 130, 63-74, 2001.
Fuentes, J. D., Wang, D., Rowling, D. R., Potosnak, M., Monson, R. K., Goliff, W. S., and Stockwell, W. R.: Biogenic hydrocarbon chemistry within and above a mixed deciduous forest, J. Atmos. Chem., 56, 165-185, 2007.

Goldstein, A. H., McKay, M., Kurpius, M. R., Schade, G. W., Lee, A., Holzinger, R., and Rasmussen, R. A.: Forest thinning experiment confirms ozone deposition to forest canopy is dominated by reaction with biogenic VOCs, Geophys. Res. Lett., 31, L22106, doi:10.1029/2004GL021259, 2004.

Grünhage, L., Haenel, H. D., and Jäger, H. J.: The exchange of ozone between vegetation and atmosphere: micrometeorological measurement techniques and models, Environ. Pollut., 109, 373 392, 2000.

Güsten, H., Heinrich, G., Mönnich, E., Sprung, D., Weppner, J., Ramadan, A. B., Ezz El-Din, M. R. M., Ahmed, D. M., and Hassan, G. K. Y.: On-line measurements of ozone surface fluxes: Part II. Surface-level ozone fluxes onto the Sahara desert, Atmos. Environ., 30, 911-918, 1996.

Jäggi, M., Ammann, C., Neftel, A., and Fuhrer, J.: Environmental control of profiles of ozone concentration in a grassland canopy, Atmos. Environ., 40, 5496-5507, 2006.

Kaimal, J. C. and Finnigan, J. J.: Atmospheric Boundary Layer Flows: Their Structure and Measurement, Oxford University Press US, 289 pp., 1994.

Karl, T., Guenther, A., Jordan, A., Fall, R., and Lindinger, W.: Eddy covariance measurements of biogenic oxygenated VOC emissions from hay harvesting, Atmos. Environ., 35, 491-495, 2001.

Kormann, R. and Meixner, F. X.: An analytical footprint model for non-neutral stratification, Bound.-Lay. Meteorol., 99, 207-224, 2001.

Kurpius, M. R. and Goldstein, A. H.: Gas-phase chemistry dominates $\mathrm{O}_{3}$ loss to a forest, implying a source of aerosols and hydroxyl radicals to the atmosphere, Geophys. Res. Lett., 30, 1371, doi:10.1029/2002GL016785, 2003.

Leuning, R.: Source/sink distributions in plant canopies using Lagrangian dispersion analysis: corrections for atmospheric stability and comparison with a canopy model, Bound.-Lay. Meteorol., 96(1-2), 293-314, 2000.

Massman, W. J.: A simple method for estimating frequency response corrections for eddy covariance systems, Agr. Forest Meteorol., 104, 185-198, 2000.

Massman, W. J.: Toward an ozone standard to protect vegetation based on effective dose: a review of deposition resistances and a possible metric, Atmos. Environ., 38, 2323-2337, 2004.

Mauder, M. and Foken, T.: Documentation and instruction manual of the eddy covariance software package TK2, Universität Bayreuth, 45 pp., 2004.

McMillen, R. T.: An eddy correlation technique with extended applicability to non-simple terrain, Bound.-Lay. Meteorol., 43, 231-245, 1988.

Mészáros, R., Zsély, I. Gy., Szinyei, D., Vincze, Cs., and Lagzi, I.: Sensitivity analysis of an ozone deposition model, Atmos. Environ., 43, 663-672, 2009.

Meyers, T. P., Finkelstein, P., Clarke, J., Ellestad, T. G., and Sims, P. F.: A multilayer model for inferring dry deposition using standard meteorological measurements, J. Geophys. Res., 103, 22645-22661, 1998.

Mikkelsen, T. N., Ro-Poulsen, H., Hovmad, M. F., Jensen, N. O., Pilegaard, K., and Egelov, A. H.: Five-year measurements of ozone 
fluxes to a Danish Norway spruce canopy, Atmos. Environ., 38, 2361-2371, 2004.

Milford, C., Theobald, M. R., Nemitz, E., Hargreaves, K. J., Horvath, L., Raso, J., Dämmgen, U., Neftel, A., Jones, S. K., Hensen, A., Loubet, B., Cellier, P., and Sutton, M. A.: Ammonia fluxes in relation to cutting and fertilization of an intensively managed grassland derived from an inter-comparison of gradient measurements, Biogeosciences, 6, 819-834, 2009, http://www.biogeosciences.net/6/819/2009/.

Moore, C. J.: Frequency response corrections for eddy correlation systems, Bound.-Lay. Meteorol., 37, 17-35, 1986.

Nemitz, E., Milford, C., and Sutton, M. A.: A two-layer canopy compensation point model for describing bi-directional biosphere-atmosphere exchange of ammonia, Q. J. Roy. Meteor. Soc., 127, 815-833, 2001.

Nemitz, E., Hargreaves, K. J., Neftel, A., Loubet, B., Cellier, P., Dorsey, J. R., Flynn, M., Hensen, A., Weidinger, T., Meszaros, R., Horvath, L., Dämmgen, U., Frühauf, C., Löpmeier, F. J., Gallagher, M. W., and Sutton, M. A.: Intercomparison and assessment of turbulent and physiological exchange parameters of grassland, Biogeosciences, 6, 1445-1466, 2009a, http://www.biogeosciences.net/6/1445/2009/.

Nemitz, E., Loubet, B., Lehmann, B. E., Cellier, P., Neftel, A., Jones, S. K., Hensen, A., Ihly, B., Tarakanov, S. V., and Sutton, M. A.: Turbulence characteristics in grassland canopies and implications for tracer transport, Biogeosciences, 6, 1519-1537, 2009b, http://www.biogeosciences.net/6/1519/2009/.

NOAA: Manual of NOAA fast ozone sensor, NOAA Air Resources Laboratory, Atmospheric Turbulence and Diffusion Division, Oak Ridge, USA, 1996.

Padro, J.: Summary of ozone dry deposition velocity measurements and model estimates over vineyard, cotton, grass and deciduous forest in summer, Atmos. Environ., 30, 2363-2369, 1996.

Padro, J., Zhang, L., and Massman, W. J.: An analysis of measurements and modelling of air-surface exchange of NO-NO2O3 over grass, Atmos. Environ., 32, 1365-1375, 1998.

Pilegaard, K.: Air-soil exchange of $\mathrm{NO}, \mathrm{NO}_{2}$ and $\mathrm{O}_{3}$ in forests, Water Air Soil Poll., 1, 79-88, 2001.

Schotanus, P., Nieuwstadt, F. T. M., and DeBruin, H. A. R.: Temperature measurement with a sonic anemometer and its application to heat and moisture fluctuations, Bound.-Lay. Meteorol., 26, 81-93, 1983.

Speuser, W., Sahand, S., and Schurath, U.: A novel fast response chemilumin-escence sonde for routine soundings of stratospheric ozone up to $1.5 \mathrm{mb}$, in: Ozone in the atmosphere, edited by: Bojkov, R. D. and Fabien, P., Deepak Publishing, 747-750, 1989.
Sutton, M. A., Nemitz, E., Theobald, M. R., Milford, C., Dorsey, J. R., Gallagher, M. W., Hensen, A., Jongejan, P. A. C., Erisman, J. W., Mattsson, M., Schjoerring, J. K., Cellier, P., Loubet, B., Roche, R., Neftel, A., Hermann, B., Jones, S. K., Lehman, B. E., Horvath, L., Weidinger, T., Rajkai, K., Burkhardt, J., Löpmeier, F. J., and Daemmgen, U.: Dynamics of ammonia exchange with cut grassland: strategy and implementation of the GRAMINAE Integrated Experiment, Biogeosciences, 6, 309-331, 2009a, http://www.biogeosciences.net/6/309/2009/.

Sutton, M. A., Nemitz, E., Milford, C., Campbell, C., Erisman, J. W., Hensen, A., Cellier, P., David, M., Loubet, B., Personne, E., Schjoerring, J. K., Mattsson, M., Dorsey, J. R., Gallagher, M. W., Horvath, L., Weidinger, T., Meszaros, R., Dämmgen, U., Neftel, A., Herrmann, B., Lehman, B. E., Flechard, C., and Burkhardt, J.: Dynamics of ammonia exchange with cut grassland: synthesis of results and conclusions of the GRAMINAE Integrated Experiment, Biogeosciences Discuss., 6, 1121-1184, 2009b, http://www.biogeosciences-discuss.net/6/1121/2009/.

Vingarzan, R.: A review of surface ozone background levels and trends, Atmos. Environ., 38, 3431-3442, 2004.

Webb, E. K., Pearman, G. I., and Leuning, R.: Correction of flux measurements for density effects due to heat and water vapour transfer, Q. J. Roy. Meteor. Soc., 106, 85-100, 1980.

Weidinger, T., Ács, F., Mészáros, R., and Barcza, Z.: Energy budget components in a forest clearcut: analysis of measurement results, Idõjárás, 103, 145-160, 1999.

Weschler, C. J.: Ozone's Impact on Public Health: Contributions from Indoor Exposures to Ozone and Products of Ozone-Initiated Chemistry, Environ. Health Persp., 114, 1489-1496, 2006.

Zhang, L., Moran, M. D., Makar, P. A., Brook, R., and Gong, S.: Modelling gaseous dry deposition in AURAMS: a unified regional air-quality modelling system, Atmos. Environ., 36, 537560, 2002a.

Zhang, L., Brook, J. R., and Vet, R.: On ozone dry depositionwith emphasis on non-stomatal uptake and wet canopies, Atmos. Environ., 36, 4787-4799, 2002b.

Zhang, L., Brook, J. R., and Vet, R.: A revised parameterization for gaseous dry deposition in air-quality models, Atmos. Chem. Phys., 3, 2067-2082, 2003,

http://www.atmos-chem-phys.net/3/2067/2003/.

Zhang, L., Vet, R., Brook, J. R., and Legge, A. H.: Factors affecting stomatal uptake of ozone by different canopies and a comparison between dose and exposure, Sci. Total Environ., 370, 117-132, 2006. 